\title{
DIFFERENT MULTIDIMENSIONAL EXPLORATORY TECHNIQUES IN CLASSIFYING VARIABLES INTO QUALITATIVE CRITERIA OF SPARE PARTS SELECTION FOR PASSENGER CARS
}

\author{
Aleksander Lotko', Małgorzata Lotko', Rafał Longwic ${ }^{2}$ \\ 1 Kazimierz Pulaski University of Technology and Humanities, Malczewskiego 29 Str., 26-600 Radom, Poland, \\ e-mail: aleksander.lotko@uthrad.pl, m.lotko@uthrad.pl \\ 2 Faculty of Mechanical Engineering, Lublin University of Technology, Nadbystrzycka 36 Str., 20-618 Lublin, \\ Poland, email: r.longwic@pollub.pl
}

Received: 2016.05.06

Accepted: 2016.07.04

Published: 2016.09.01

\begin{abstract}
The aim of the paper was (1) to compare cluster analysis and factor analysis applied in the classification of variables into quality criteria of spare parts selection for passenger cars and (2) to create a metamodel taking into account the similarities and differences between the results of the carried out analyses. To collect empirical data, a survey questionnaire was used. It was built on the basis of literature overview concerning quality management. Data was processed with the use of multi-dimensional exploratory techniques: cluster analysis and factor analysis. A theoretical implication is a proposed metamodel, which joins the results of both cluster and factor analysis. A practical implication is a possibility of taking an advantage on the obtained results when planning, designing, manufacturing, distributing, selecting and selling spare parts for passenger cars. Paper contribution is the use of exploratory data analysis techniques in the research area and the proposal of the metamodel formalizing quality criteria of spare parts selection for passenger cars. The research showed, that classifications of variables obtained with the use of two multi-dimensional exploitation techniques are different although there are distinct common elements. When using cluster analysis, the following clusters were identified: marketing, economy and utility one (arranged in accordance with the order of linking). While when using factor analysis, the following factors were discovered: utility, marketing, availability and cost factor (arranged in descending way in accordance with the explained variance).
\end{abstract}

Keywords: spare parts quality, passenger cars, qualitative criteria, multidimensional exploratory techniques.

\section{INTRODUCTION}

In recent years, the automobile industry has been struggling with the decrease in sale caused by the financial crisis and technological restrictions resulting from the necessity of environment protection. At the same time we observed the shortening of the development cycle and presence of the automotive industry products in the market together with the simultaneous increase in their complexity. The issue of the quality in the automotive industry is of particular importance for five reasons [16]:

1) Complexity of the product (a car is composed of more than ten thousand of parts).

2) Technological level of product advancement and the process of its production.

3) Quantity production and mass production.

4) Configurability and modularity of the product.

5) Necessity of close cooperation within the framework of delivery chains (only a small part of components (usually approx. 20\%) is manufactured individually by a car manufacturer and the rest comes from the sub-suppliers). 
Exploitation of cars covers the necessity of performing a number of operation and repair activities which require appropriate spare parts mounted in the pace of the worn out or faulty parts. There is a problem consisting in the selection of the parts of desired quality. It is an important and complex issue joining both marketing and commodity science and it cannot be limited merely to evaluation criteria.

The purpose of this paper was to (1) compare the cluster analysis and factor analysis in the classification of variables into quality criteria of the spare parts selection and to (2) create a metamodel taking into account the similarities and differences between the results of the carried out analyses. Thus the following working hypotheses have been posed:

- H1: classifications of variables obtained with the use of two multi-dimensional exploitation techniques are different although there are distinct common elements.

- H2: cluster model suggests the acceptance of less homogenous criteria and of larger informational capacity (number of variables).

- H3: factor model suggests the acceptance of criteria of more detailed and homogenous character.

- H4: factor model classifies the smaller number of variables than the cluster model.

The above hypotheses were verified with the use of the cluster and factor analysis.

\section{ANALYSIS OF THE STATE OF THE ISSUE}

Carried out literature analysis demonstrates the relevance and importance of the discussed topic and at the same time the existence of a research gap. Available elaborates are mainly focused on the system recognition of the relations between the parts manufacturer and cars manufacturer [28], management of the quality of suppliers [17], costs of the quality of suppliers [24], methods and devices used for the management of the quality in the automotive industry [22], systems, standards conditioning of the implementation of quality management in the automotive industry [6], effectiveness of the quality management systems [19], management of supplies chains [7] or applications of the quality management systems by suppliers [1]. As it comes to the precise issue concerning the quality of parts, in the analysed elaborates, it covered the control at the produc- tion stage and directly after it [14], standardization of the quality tests including the reliability for the parts manufacturers [4], quality challenges and the outline of directions of quality improvement for parts manufacturers [20], quality of the parts in the context of the calling actions [8] or the issues connected with logistics and packaging of automotive parts [29].

No paper covering the results of the research on the classification of quality criteria of the selection of spare parts, from the point of view of the client, has been found. Taking this research gap into account, in this paper the author made an attempt to compare the quality criteria of the selection of parts obtained with the use of two different multi-dimensional exploratory techniques.

\section{QUALITY OF SPARE PARTS FOR PASSENGER CARS}

By confronting the model of J. Żuchowski [30] with the discussed issues, it was found that the quality of passenger cars spare parts and in particular their usability value is determined by the following factors:

- reliability - i.e. fulfilment of particular requirements in every conditions and time. A passenger car is a special good and it should be efficient in order not to threaten the safety of both the driver, passengers and other users of the road.

- functionality - in case of the spare parts this means the performance of a particular task at the expected level (for example the attainment of a high value of delays by the brake blocks and brake shields, high tire grip, good roughness dampening by the shock absorbers),

- durability - concerns the time of exploitation of the parts between the repairs for those parts which may be regenerated (for example the clutch, steering gears, cylinder head, some injectors),

- efficiency - concerns the time of the work performed by the parts in which it performs its function in a desired way in respect of the entire possible time of its work (for example the shock absorbers after achieving a particular wear and tear dampen the roughness in a poor way and may make the car body swing, xenon lights with time change the colour of the emitted light and the tires drain off the water less effectively with the wear and tear of the tire tread), 
- vivacity - the majority of the parts is worn out with time, especially those located in the suspension, break system but also the engine accessories,

- repairability - due to the economy and ecology reasons some parts, instead of being utilized may be subject to regeneration in order to be reused (for example the clutch, steering gears, suspension components (twist-beams), starters, alternators),

- modernity - fulfilment of users requirements within the scope of aesthetics, use of the newest materials (aluminium, fibres, ceramic elements) as well as modern design achievements (elements of the body, external lighting, interior equipment),

- safety - particularly important feature due to the significant risk in the road traffic. First of all it concerns the active safety i.e. particular parts prevent the occurrence of the said risk (for example the short breaking path thanks to the high quality of break blocks, shock absorbers and tires, appropriate lighting on the road in front of a vehicle thanks to the efficient headlights). Secondly it covers passive safety i.e. minimization of the negative effects of accidents (proper functioning of airbags, belt stretchers, protection provided by the areas of controlled body crumpling).

In addition to the mentioned features, the product usability value is also determined by the quality of its performance. One of the most renowned definitions is the one proposed by $\mathrm{T}$. Kotarbiński [12] adroitness of product i.e. the sum of the quality of the type and performance. The first one is among others the degree of product compliance with the norms, technical standards and legal provisions. In case of the spare parts, it should be taken into consideration that besides the compatibility with physical parameters (for example adjustment of body components), the majority of them is subject to homologation i.e. it must have the permission to be used within the territory of the country, granted by an authorized institution. The adroitness of a product is also determined by the quality of performance constituted by the degree of representation of the type quality requirements.

Except for the efficiency and compatibility with technical specification, the quality of performance may also cover the aesthetic values. In case of the spare parts they may include the sup- porting factors, however they should not be neglected. Obviously the aesthetic criterion applies mainly to the visible components of the interior equipment (special compartments for flowers in Volkswagen New Beetle) and the car body elements (it is difficult to talk about the aesthetics of a clutch or shock absorber). We may also mention the aesthetics when talking about the product packaging, however its contents is more important. Protection and informational functions of a packaging are of greatest importance in this particular case.

When discussing the technical aspect of the quality we should mention the operational quality which except for the technical parameters of the use and wear and tear is also determined by the form of the sale and after-sale service (for example the repairs and current or warranty checkups). When elaborating the spare parts, a certain period of operational usability is assumed and the said period is most frequently measured by the trouble-free mileage. The economy of using is an indispensable element as it covers the economy of operation within the scope of taking advantage of the check-up services and economy of operation connected with the everyday exploitation of a vehicle.

The ecological aspect of the use of the spare parts is also very important. Nowadays the life cycles of a number of products are significantly shortened and the utilization of worn out products is becoming a global problem. In order to limit the production and storage of waste, a process of regeneration of used spare parts for passenger cars has been commenced and propagated in the recent years. Apart from the environmental aspect this solution brings savings for the users of vehicles as the regenerated spare parts are much cheaper.

\section{RESEARCH METHODOLOGY}

At first the operationalization of the terms within the scope of the quality attributes of the spare parts was carried out. On the basis of the above presented analysis of the literature research within the scope of product quality issue $[30 ; 12$; $11 ; 18 ; 5 ; 21 ; 10 ; 23 ; 27]$ concerning the quality of products compared to the specificity of the passenger car parts, 21 observable variables have been selected. They were numbered in the following way: 1 - reliability, 2 - functionality, 3 -durability, 4 - efficiency, 5 - vivacity, 6 - repair- 
ability, 7 - modernity, innovativeness, 8 -safety, 9 - degree of compatibility with the pattern, 10 - aesthetics, trends, 11 - presentation (form of offer, sale and pre-sale service, 12 - greenness, 13 - fulfilment of the norms and legal regulations, 14 - diligence of performance, 15 - terms of warranty, 16 - price, 17 - economy of installation and use (exploitation), 18 - availability, 19 - speed of delivery, 20 - brand image and reputation of a supplier, 21 - packaging (aesthetics, included information).

Values of the variables were measured on the five-point scales of the Osgood semantic balanced gear. The simplest version of these scales was applied with two opposite adjectives on the edges. The five-point scale from 1 -immaterial to 5 - critical was applied for the evaluation of the importance of attributes.

Research was carried out with the application of the survey method. The selection of the research sample was of purposive nature. The research was conducted on the clients of authorized automotive service stations and independent workshops. The number of 498 correctly filled in questionnaires was obtained and subjected to further analysis. The research was carried out from 7 to 23 October 2015.

The analysis of clusters and factor analysis is a two statistical and explorative technique used for data analysis. They are frequently applied in the nature and behavioural science. The concept of cluster analysis was introduced by Tryon [26], and subsequently developed by Cattell [2]. Cluster analysis covers a number of various algorithms and methods of grouping objects of similar kind into appropriate categories. It enables explorative analysis of data by sorting various objects into such groups so that the degree of similarity between two objects is maximal when they belong to the same group and minimal when otherwise. The purpose of the analysis is putting the objects of one clusters into groups in a way that the objects belonging to a given cluster have more in common with each other that with the objects belonging to other clusters. This technique is successfully applied in various areas [15].

Factor analysis was elaborated and developed in the Anglo-Saxon psychology. It was described for the first time by Spearman in 1904. However the theoretical basics and possibilities of practical solutions was elaborated by Thursone [25]. Lawley and Maxwell [13] formulated the factor analysis as a formal statistical model. It is composed of a set of methods and statistical procedures which allow for the reduction of a significant number of examined variables to a smaller number mutually independent (not correlated) factors. Distinguished factors in their assumption are connected with the deeper level of examined reality (for example attitudes, values) and constitute the reasons laying at the bottom of observable variables. In this paper we applied the method of the main components which is a typical method of the classification of variables.

\section{ANALYSIS OF THE RESEARCH RESULTS AND THEIR COMPARISON}

Classification of observable variables into homogenous sets which were called the quality criteria of the selection of spare parts, was taken into consideration. At first the analysis of clusters was applied. Observable variables were joined into clusters with the use of agglomeration (Ward method). Icicle chart presented in figure 1 demonstrates clusters obtained in the next steps, whereas the chart in Figure 2 illustrates the increase the length of the connection in the next steps.

When analysing figure 1 , it was discovered that the obtained classification is technically quite simple to interpret. It is clearly demonstrated that the cut off in the chart with the standardized distance for example 40 gives three obvious subset (clusters) of variables. It is confirmed by the chart in figure 2 which suggests the place of the cut off in the icicle chart; it shows a considerable increase in the distance in the last two steps of the analysis, where the cut off of the chart should be performed. Then it may be assumed that the identified clusters indeed reflect distinct homog-

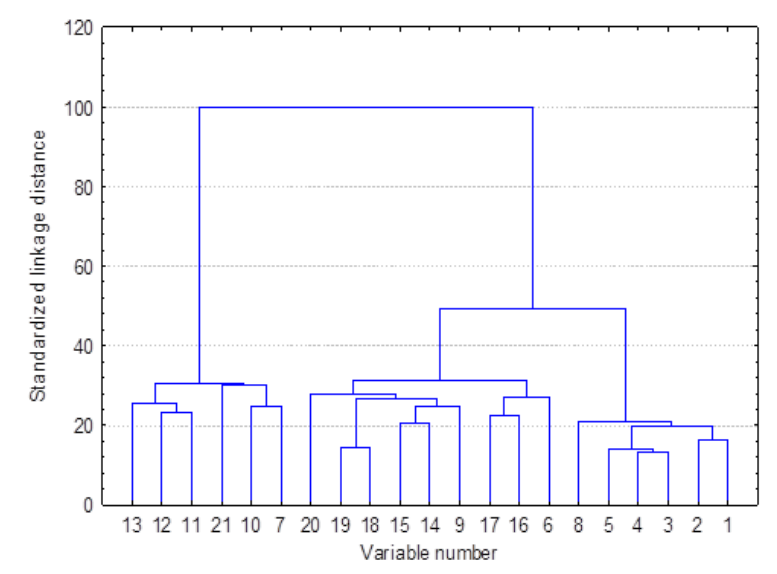

Fig. 1. Results of the cluster analysis for variables presented in the icicle chart 


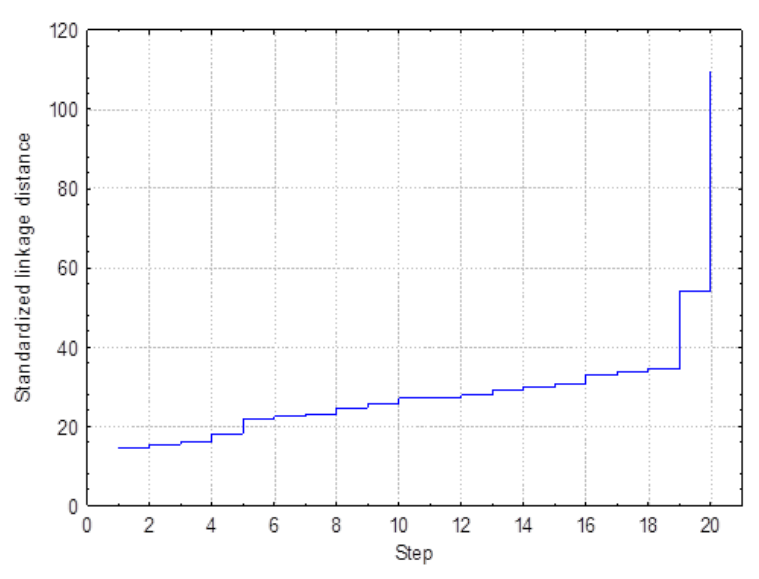

Fig. 2. Distance between the connections in the next steps of the cluster analysis for variables

enous groups in respect of variations of variables. Therefore a solution with three clusters were selected for further analysis.

Interpretation of the obtained clusters is as follows (the order of the connection of variables was maintained therefore they are not sorted) [16]:

1. Cluster 1 covers six variables: 13 - fulfilment of the norms and legal regulations, $12-$ greenness, 11 - form of presentation (offering of the sale and pre-sale service), 21 - aesthetics of packaging and information included in it, 10 - aesthetics, trends and 7 - modernity and innovativeness of parts. This cluster is called a marketing cluster and marked with the letter "M".

2. Cluster 2 covers nine variables: 20 - brand image and reputation of supplier, 19 - speed of delivery, 18 - availability, 15 - terms of a warranty, 14 - diligence of performance, 9 degree of compatibility with the pattern, 17 - economy of installation and exploitation, 16 - price and 6 - repairability of parts. This dimension is the most capacious one in respect of information and it is concentrated on the most semantically diverse variables. This cluster is called the economic cluster and is marked with the letter ,E".

3. Cluster 3 covers six variables: 1 - reliability, 2 - functionality, 3 - durability, 4 - dexterity, 5 - vivacity and $8-$ safety of parts. This cluster is called the utility cluster and marked with the letter ,U”.

Reliability of obtained scales was examined with the use of $\alpha$-Cronbach measure. For the marketing and economic clusters the same value of 0,85 was obtained and for the utility cluster the value of 0.92 . All these values are significantly higher than the suggested border value 0.6 .

It should be mentioned that the obtained structure of the model proved to be slightly equivocal in interpretation. Provided that from the technical view the adopted division into 3 clusters is very clear, the informational content i.e. semantic layer of the first two clusters is rich and equivocal. Hypothesis $\mathrm{H} 2$ was verified in the same way.

Subsequently the factor analysis was applied, i.e. the analysis of the main components (Principal Component Analysis). Figure 3 presents the chart of factorial scree, according to the Cattell criterion [3].

Pursuant to the R. Cattell criterion such number of factors should be assumed, for which the "slope" of the scree begins to flatten. Figure 1 presents that the discussed example there are four factors. The next selected factors are of a small Eigenvalue so they do not include too much information and should be rejected. On the other hand table 1 includes Eigenvalues of factors and the percentage of general variances explained by them.

The Eigenvalue informs about the fact which part of the entire variability is 'translated' by a given factor. Pursuant to the Kaiser criterion [9], factors of Eigenvalues higher than 1 should be maintained in the analysis. Bearing in mind two above mentioned criteria, the solution with four factors was chosen, while the values of the last factor is slightly higher than the value recommended by Kaiser (1,02 towards 1 ), thus we may probably resign from it in the explanation of the structure of the examined construct.

Table 2 presents factor charges for combination variable-factor. They are interpreted as correlations between the factors and variables.

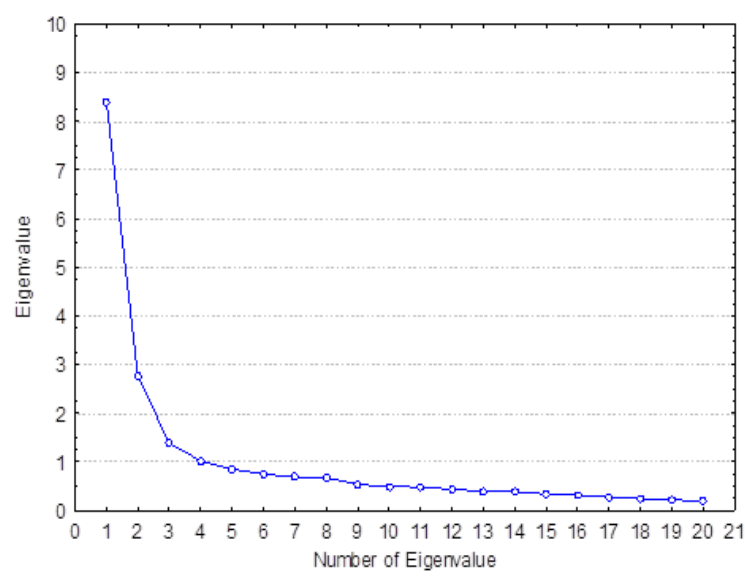

Fig. 3. Factorial scree - Eigenvalues of separated factors 
Table 1. Eigenvalues of factors and the explained percentage of variances

\begin{tabular}{|c|c|c|}
\hline Factor & Eigenvalue & $\begin{array}{c}\% \text { of the totality of } \\
\text { variances }\end{array}$ \\
\hline Factor 1 & 8.40 & 40.00 \\
\hline Factor 2 & 2.76 & 13.20 \\
\hline Factor 3 & 1.39 & 6.60 \\
\hline Factor 4 & 1.02 & 4.80 \\
\hline
\end{tabular}

Values of the factor charges for all combinations of factors are also presented in Figure 4.

On the basis of table 2 the following four factorial solution was adopted:

1. Factor 1 is loaded by six variables: 1 - reliability, 2 - functionality, 3 - durability, 4 dexterity, 5 - vivacity and 8 - safety of spare parts. This factor is called the utility and marked with the letter "U".

2. Factor 2 is indeed loaded by five variables: 10 - aesthetics, trends, 11 - form of the offering, sale and pre-sale service, 12 - greenness and 21 - packaging (aesthetics, placed information). Due to the contents of the said variables, this factor is called the marketing and is marked with the letter "M".

Table 2. Factor charges for combination factor-variable (values $>0,6$ were distinguished)

\begin{tabular}{|c|c|c|c|c|}
\hline Variable & Factor 1 & Factor 2 & Factor 3 & Factor 4 \\
\hline 1 & 0,88 & 0,01 & 0,11 & 0,05 \\
\hline 2 & 0,76 & 0,27 & $-0,01$ & 0,16 \\
\hline 3 & 0,87 & 0,03 & 0,18 & 0,12 \\
\hline 4 & 0,81 & 0,13 & 0,16 & 0,28 \\
\hline 5 & 0,74 & 0,06 & 0,21 & 0,30 \\
\hline 6 & 0,36 & 0,30 & $-0,07$ & 0,61 \\
\hline 7 & 0,33 & 0,66 & 0,03 & 0,16 \\
\hline 8 & 0,71 & 0,12 & 0,23 & 0,11 \\
\hline 9 & 0,43 & 0,39 & 0,25 & 0,24 \\
\hline 10 & 0,09 & 0,78 & $-0,10$ & 0,23 \\
\hline 11 & 0,10 & 0,77 & 0,18 & 0,12 \\
\hline 12 & 0,18 & 0,75 & 0,25 & $-0,14$ \\
\hline 13 & 0,26 & 0,61 & 0,34 & $-0,09$ \\
\hline 14 & 0,52 & 0,33 & 0,39 & 0,07 \\
\hline 15 & 0,53 & 0,20 & 0,56 & 0,01 \\
\hline 16 & 0,16 & 0,03 & 0,31 & 0,68 \\
\hline 17 & 0,28 & 0,20 & 0,28 & 0,63 \\
\hline 18 & 0,23 & 0,13 & 0,73 & 0,39 \\
\hline 19 & 0,23 & 0,23 & 0,75 & 0,23 \\
\hline 20 & 0,06 & 0,51 & 0,40 & 0,39 \\
\hline 21 & $-0,18$ & 0,74 & 0,13 & 0,25 \\
\hline
\end{tabular}
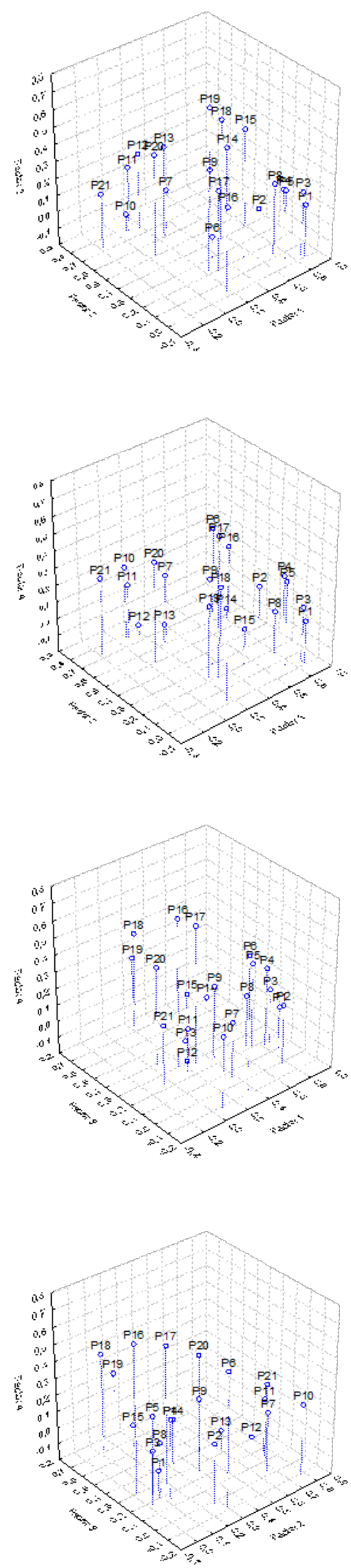

Fig. 4. Values of the factor charges in three-dimensional space for all combinations of factors 
3. Factor 3 includes significant factor charges for two variables: 18 - availability and 19 - speed of delivery. This factor is called the availability and marked with the letter "A".

4. Factor 4 is significantly correlated with three variables: 6 - repairability, 16 - price and 17 - economy of installation and use. This factor is called the cost factor and is marked with the letter "C".

Bearing in mind that the contents of particular factor, it is obvious that hypothesis $\mathrm{H} 3$ was verified.

Reliability of obtained measuring scales was re-examined with the use of $\alpha$-Cronbach measure. Value of 0,92 was obtained for the utility factor, 0,82 for the marketing factor, the case of availability was not examined (at least three variables are required and this factor is loaded only by two), whereas the $\alpha$-Cronbach values for the cost factor amounted to 0,68 .

As a result of the application of both types of the analysis we obtained the association of the variables with the quality criteria of the selection of parts, what is collectively presented in table 3. In this way, a metamodel taking into account the similarities and differences between the results obtained with the use of two different multi-dimensional exploratory techniques, was elaborated.

The analysis of the metamodel included in table 3 demonstrates that the utility criterion (U) is identical in both cases. Both in case of the results of the cluster analysis and factor analysis, it covers the same variables: 1 - reliability, 2 - functionality, 3 - durability, 4 - dexterity, 5 - vivacity and 8 - safety. Three criteria obtained as a result of the cluster analysis have larger informational capacity. In other words - they are less unequivocal. And so, the economy cluster (E) combines all three variables included in the cost factor (C) (6 - repairability, 16 - price, and 17 - economy of installation and use), both variables (18 - availability and 19 - speed of delivery) constituting the factorial criterion of availability (A) as well as four other variables. Thus the economy criterion (E) in the cluster analysis covers two additional criteria, cost and availability disclosed in factor analysis. As far as the marketing criterion (M) is concerned, in both cases four variables are common: 10 - aesthetics, trends, 11 - presentation, 12 - greenness and 21 - packaging (aesthetics

Table 3. Metamodel - comparison of the assignment of variables to the clusters and factors

\begin{tabular}{|c|c|c|c|}
\hline Variable & Attribute & $\begin{array}{c}\text { Assignment to the CLUS- } \\
\text { TER (prefix with variable } \\
\text { number) }\end{array}$ & $\begin{array}{l}\text { Assignment to the } \\
\text { FACTOR (prefix with } \\
\text { variable number) }\end{array}$ \\
\hline 1 & Reliability & U1 & U1 \\
\hline 2 & Functionality & U2 & U2 \\
\hline 3 & Durability & U3 & U3 \\
\hline 4 & Dexterity & U4 & U4 \\
\hline 5 & Vivacity & U5 & U5 \\
\hline 6 & Repairability & E1 & C1 \\
\hline 7 & Modernity, innovativeness & M1 & - \\
\hline 8 & Safety & U6 & U6 \\
\hline 9 & Degree of compatibility with the pattern & E2 & - \\
\hline 10 & Aesthetics, trends & M2 & M1 \\
\hline 11 & Presentation (form of offering, sale and pre-sale service) & M3 & M2 \\
\hline 12 & Greenness & M4 & M3 \\
\hline 13 & Fulfilment of norms and legal regulations & M5 & - \\
\hline 14 & Diligence of performance & E3 & - \\
\hline 15 & Terms of warranty & E4 & - \\
\hline 16 & Price & E5 & $\mathrm{C} 2$ \\
\hline 17 & Economy of installation and use (exploitation) & E6 & C3 \\
\hline 18 & Availability & E7 & A1 \\
\hline 19 & Speed of delivery & E8 & $\mathrm{A} 2$ \\
\hline 20 & Brand image and reputation of supplier & E9 & - \\
\hline 21 & Packaging (aesthetics, included information) & M6 & M4 \\
\hline
\end{tabular}


and included information). In case of the cluster analysis two variables are added: 7 - modernity, innovativeness and 13 - fulfilment of norms and legal regulations. In factor analysis, the variables with weak correlations with the factors, i.e. low factor charges were dismissed form the model. In this way we verified hypothesis H1.

Additionally it should be notices that in general due to the weak correlations with factors, six variables were rejected from the factor model. They concern the following variables: 7 - modernity, innovativeness, 9 - degree of compatibility with the pattern, 13 - fulfilment of norms and legal regulations, 14 - diligence of performance, 15 - terms of warranty, 20 - brand image and reputation of supplier. Thus the factor model classifies the smaller number of variables than the cluster model (15 towards 21). Thus we verified hypothesis $\mathrm{H} 4$.

In this way we completed the comparison of the classification of variables with the use of both exploratory techniques.

\section{CONCLUSIONS}

As a result of the carried out analysis the following conclusions were drawn:

1. In cluster analysis, the observation of the increase in the length of the binding and the semantic analysis included in the clusters suggested the adoption of the solution with three clusters. The following clusters were identified: marketing, economy and utility one (arranged in accordance with the order of linking).

2. In factor analysis both the Cattell criterion and Kaiser criterion suggested the adoption of the four factorial solution (although due to the low Eigenvalue the fourth factor should be probably rejected). The following factors were discovered: utility, marketing, availability and cost factor (arranged in descending way in accordance with the explained variance).

3. The elaborated metamodel shows that the classifications of variables into quality criteria of the selection of spare parts for two multidimensional exploratory techniques differ, although there are some common elements such as utility criterion (covering 6 variables) and a considerable part of the marketing criterion (4 variables: in cluster analysis there are 2 additional variables).
4. In factor analysis we distinguished separate factors describing the availability and costs of the parts. Variables charging these factors in the cluster analysis are the components of the economy criterion.

5. Cluster model suggests the adoption of less homogenous criteria and of larger informational capacity (three clusters joining 6,9 and 6 variables respectively).

6. Factor model suggests the adoption of criteria of more detailed and homogenous character (4 factors loaded by 6, 5,2 and 3 variables respectively).

7. Factor model classifies the smaller number of variables than the cluster model (15 towards 21).

8. All obtained criteria are reliable. This concerns both the clusters and the factors. For the last factor (cost factor) the reliability is definitely the lowest.

In general, in this paper we demonstrated the usefulness of multi-dimensional exploratory methods in the discussed area.

\section{REFERENCES}

1. Bevilacqua M. et al., Overview on the application of ISO/TS 16949:2009 in a worldwide leader company in the production of stainless steel tubes for automotive exhaust systems. International Journal of Manufacturing Technology and Management; 7 (4), 2011, 410-439.

2. Cattell R., A note on correlation clusters and cluster search methods. Psychometrica; 9, 1944, 169-184.

3. Cattell R., The Scree Test for the Number of Factors. Multivariate Behavioral Research; 1, 1966, 245-276.

4. Franceschini F., Maisano D., Standardisation of quality and reliability tests in the auto-parts industry: a structured approach concerning thermal systems. Total Quality Management and Business Excellence; 12, 2015, 1269-1281.

5. Garvin D., Competing on the Eight Dimensions of Quality. Harvard Business Review; 6, 1987, 65.

6. Hoyle D., Automotive Quality Systems Handbook. Elsevier, 2005.

7. Jang G.-S., Choi J.-S, Parts supply management system for automobile parts manufacturing companies. Asian Journal on Quality; 4, 2003, 213-221.

8. Jie M., Horie M., Auto Parts Suppliers Under Pressure Following Recalls. Insurance Journal; January 19, 2015. 
9. Kaiser H., The Varimax Criterion for Analytic Rotation in Factor Analysis. Psychometrika; 23, 1958, 187-200.

10. Karpiel Ł., Skrzypek M., Towaroznawstwo ogólne. Wydawnictwo Akademii Ekonomicznej w Krakowie, Kraków, 2000.

11. Kindlarski E., Jakość wyrobów. PWN, Warszawa, 1998.

12. Kotarbiński T., Traktat o dobrej robocie. Ossolineum, Łódź, 1955.

13. Lawley D., Maxwell A., Factor Analysis as a Statistical Method. Butterworth, London, 1963.

14. Lin C. et al., Research on Solder Joints Quality Detection of Auto Parts Based on Biological Vision Feature. Advanced Materials Research; 712-715, 2013, 2385-2388.

15. Lotko M., Lotko A., Cluster Analysis of Knowledge Workers' Assessment of Occupational Threats and Attitudes to Character of Work. Eksploatacja i Niezawodnosc - Maintenance and Reliability; 17 (1), 2015, 80-89.

16. Lotko M., Lotko A., Jakościowe kryteria doboru części do samochodów osobowych, ITeE-PIB, Radom, 2016.

17. Łuczak J., System zarządzania jakością dostawców w branży motoryzacyjnej - analiza istotności wymagań. Wyd. Akademii Ekonomicznej w Poznaniu, Poznań, 2008.

18. Łunarski J., Zarządzanie jakością. Standardy i zasady. Wydawnictwa Naukowo-Techniczne, Warszawa, 2008.

19. Mazurkiewicz J., Banaszak I., Wierzbicka M., Efektywność systemu zarządzania jakością ISO/TS 16949. Ekonomika i Organizacja Przedsiębiorstwa; 4, 2010, 72-79.
20. Mzalwane A., Susila M., Shamsuddin A., Automotive Parts Manufacturing Industry: Unravelling the Efficacious Quality Framework. Interdisciplinary Journal of Contemporary Research in Business; 4 (3), 2012, 217-226.

21. Prussak W., Zarządzanie jakością. Wybrane elementy. Wydawnictwo Politechniki Poznańskiej, Poznań, 2006.

22. Punnakitikashem P. et al., A study of quality management practices in TQM and non-TQM firms: Findings from the ASEAN automotive industry. International Journal of Quality \& Reliability Management; 27 (9), 2010, 1021-1035.

23. Skrzypek E. (ed.), Dojrzałość jakościowa a wyniki przedsiębiorstw zorientowanych projakościowo, Difin, Warszawa, 2013.

24. Teli S. et al., Assessment of supplier quality cost in automobile industry. International Journal of Manufacturing Technology and Management; 4 (1), 2014, 1-20.

25. Thurstone L., Multiple Factor Analysis. University of Chicago Press, Chicago, 1947.

26. Tryon R., Cluster Analysis. McGraw-Hill, New York, 1939.

27. Urbaniak M., Zarządzanie jakością. Teoria i praktyka. Difin, Warszawa, 2004.

28. Urbaniak M., Kierunki doskonalenia systemów zarządzania jakością, Wydawnictwo Uniwersytetu Łódzkiego, Łódź, 2010.

29. Zhang Q., Returnable packaging management in automotive parts logistics: Dedicated mode and shared mode. International Journal of Production Economics; 168, 2015, 234-244.

30. Żuchowski J., Jakość i ekologia. Wydawnictwo Politechniki Radomskiej, Radom, 1999. 